\title{
ROLA WARTOŚCI W FUNKCIONOWANIU SPOŁECZNOŚCI MAREK. STUDIUM PRZYPADKU MARKI IKEA I SPOŁECZNOŚCI IKEAHACKERS
}

\section{Abstract \\ THE ROLE OF VALUES IN BRAND COMMUNITIES. CASE STUDY OF IKEA AND IKEAHACKERS COMMUNITY}

Linking values of brand communities are the subject of the analysis. Various types of consumption communities are not a new phenomenon, however, the development of communication technologies in recent two decades has significantly impacted on the number and character of such groups. Relationship between brands and brand communities has become interesting research field due to growing importance of such groups in consumers' lives as well as their marketing potential. Recent studies highlight the role of values in emerging and functioning of brand communities. The purpose of this case study analysis is to examine the relationship between strategic brand values and linking values of brand community on the example of IKEA and IKEAhackers community. This case confirms earlier hypotheses that brand communities are autonomous, and brand strategic values are neither automatically nor uncritically accepted by the community as linking values of the community. Such groups may accept the values proposed by the brand managers, however, they may also reinterpret them, reject, recognize as irrelevant or consider different values as linking values of brand community.

Key words: brand community, consumption community, marketplace community, consumer tribes, brand strategy, brand values, linking value

\section{Wstęp}

Rozwój Internetu zaowocował powstaniem nowego rodzaju wspólnot: społeczności wirtualnych. Możliwość wielostronnej komunikacji na odległość zniosła barierę, jaką dla wytworzenia się więzi społecznych stanowiła wcześniej konieczność kontaktów twarzą w twarz. Jednocześnie zmienił się też charakter relacji: o ile 
w tradycyjnych wspólnotach podstawą wspólnej identyfikacji była bliskość geograficzna (grupy sąsiedzkie, koleżeńskie, zawodowe itp.), o tyle główną motywacją do uczestnictwa w życiu społeczności wirtualnych stały się wspólne zainteresowania ${ }^{1}$.

Obecnie Internet jest podstawową platformą komunikacji społeczności konsumenckich, w tym tych skupionych wokół marek. Tego typu grupy, jak choćby kluby miłośników motocykli Harley-Davidson bądź fandomy zrzeszające wielbicieli Gwiezdnych wojen czy komiksów Marvela, nie są zjawiskiem nowym, jednak możliwości technologiczne przyczyniły się do wzrostu ich popularności i liczebności ${ }^{2}$. Robin Canniford $^{3}$ wyróżnia trzy typy społeczności konsumenckich: subkultury konsumpcyjne, społeczności marek oraz plemiona konsumentów. Pierwszy typ odnosi się do grup funkcjonujących - zgodnie z socjologiczną koncepcją subkultur - na marginesie głównego nurtu kulturowego (w tym wypadku związanego $\mathrm{z}$ aktywnościami konsumpcyjnymi). Drugi typ - społeczności marek - to wspólnoty, dla których podstawą więzi pomiędzy członkami jest określona postawa względem konkretnej marki. Wreszcie trzeci typ - plemiona konsumenckie - to zbiorowości, w których relacje powstają na podstawie wspólnych doświadczeń związanych z korzystaniem z produktów i usług.

Przedmiotem zainteresowania niniejszego artykułu są społeczności marek, które Albert M. Muñiz i Thomas C. O’Guinn ${ }^{4}$ definiują jako wyspecjalizowane i niepowiązane geograficznie wspólnoty, zbudowane na podstawie sieci relacji społecznych pomiędzy wielbicielami danej marki. Członków takich grup cechuje świadoma przynależność oraz poczucie, że ich relacja z marką oraz innymi przedstawicielami społeczności jest czymś ważnym. W społecznościach marek żywe są tradycje i rytuały, a głównym motywatorem kolektywnego działania jest moralna odpowiedzialność za wspólnotę. Ich członkowie dzielą się wiedzą i doświadczeniem, doradzają sobie w zakresie użytkowania produktów marki, wspólnie je modyfikują bądź naprawiają. Czują się też odpowiedzialni za pozyskiwanie nowych członków społeczności, którzy zapewnią jej trwanie ${ }^{5}$.

Rozwój wirtualnych społeczności marek powoduje, że współcześnie atrakcyjną propozycją dla osób zarządzających markami staje się tzw. branding społeczny, czyli koncepcja budowania marki opartej na więzi społecznej. Sieci społeczne mogą być dla organizacji narzędziem budowania relacji z klientami, pomagać w obniżeniu kosztów promocji, a także uczestniczyć w kreowaniu pożądanego wizerunku

1 H. Rheingold, The Virtual Community, https://www.rheingold.com/vc/book/ (dostęp: 3.11.2019).

2 P. Siuda, Wpływ Internetu na rozwój fandomów, czyli o tym, jak elektroniczna sieć rozwija i popularyzuje społeczności fanów, [w:] M. Sokołowski (red.), Media i społeczeństwo. Nowe strategie komunikacyjne, Wydawnictwo Adam Marszałek, Toruń 2008, s. 240.

3 R. Canniford, A Typology of Consumption Communities, [w:] R.W. Belk i in. (red.), Research in Consumer Behavior, Emerald Publishing, Bigley 2011, s. 57-75.

4 A. Muñiz, T. O’Guinn, Brand Community, ,Journal of Consumer Research” 2001, nr 27 (4), s. 412.

A. Muñiz, T. O'Guinn, Marketing Communications in a World of Consumption and Brand Communities, [w:] A.J. Kimmel (red.), Marketing Communication: New Approaches, Technologies, and Styles, Oxford University Press, Oxford 2005, s. 65-66. 
marki poprzez wyrażane przez ich członków opinie i rekomendacje ${ }^{6}$, stąd też niejedna marka chciałaby móc dysponować takim potencjałem. W dobie mediów społecznościowych wydawać by się mogło, że kluczem do zbudowania wspólnoty wokół marki są narzędzia umożliwiające bezpośrednią komunikację z odbiorcami. Praktyka brandingu wskazuje jednak, że same narzędzia to za mało. Dotychczasowe opracowania naukowe podkreślają natomiast kluczową rolę wartości w powstawaniu i funkcjonowaniu tego typu wspólnot.

Celem niniejszego artykułu jest zaprezentowanie wyników analizy relacji między wartościami strategicznymi marki a wartościami spajającymi społeczność skupioną wokół tejże marki, na konkretnym przykładzie marki IKEA i społeczności IKEAhackers. Zastosowana metoda studium przypadku służyć ma - zgodnie z założeniami nurtu humanistycznego nauk o zarządzaniu - poznaniu mechanizmów zarządzania z pespektywy człowieka ${ }^{7}$, czyli w tym wypadku przedstawicieli dwóch grup: członków społeczności marki oraz osób zarządzających marką.

Z punktu widzenia problematyki zarządzania mediami obie te perspektywy są istotne. Pierwsza ukazuje mechanizmy powstawania i funkcjonowania społeczności konsumenckich w Internecie: od sposobu korzystania z nowych mediów przez proces budowania więzi społecznych aż po formy wywierania wpływu przez wirtualne społeczności konsumenckie. Druga perspektywa dotyczy zarządzania kanałami i komunikacją marki w kontekście kontroli nad kształtowaniem swego wizerunku oraz budowania relacji ze społecznościami marek.

Choć głównym przedmiotem niniejszego artykułu są społeczności marek, dla zachowania logiki wywodu w pierwszej kolejności omówione zostaną wartości strategiczne marki, natomiast w drugiej - wartości spajające wspólnotę. Wynika to $\mathrm{z}$ faktu, że istnienie marki jest warunkiem koniecznym powstania społeczności tejże marki, zatem wartości strategiczne marki mają pierwotny charakter w stosunku do wartości spajających wspólnotę. Zaprezentowana poniżej analiza koncentruje się bowiem na sposobach określania przez społeczności marek swojego stosunku do wartości strategicznych zaproponowanych przez same marki.

\section{Wartości strategiczne marki oraz wartości spajające wspólnotę wokół marki - dylematy definicyjne}

Termin „wartość” w języku zarówno angielskim, jak i polskim jest wieloznaczny, stąd też w literaturze poświęconej zarządzaniu marką jest on używany w różnych kontekstach. Pierwsze, najbardziej podstawowe rozumienie tego terminu odnosi

6 J. Kreft, Zarządzanie wspóltworzeniem wartości w mediach. Od łańcucha do konstelacji, „Problemy Zarządzania” 2013, nr 11/4, s. 161.

7 J. Kociatkiewicz, M. Kostera, Zarządzanie humanistyczne. Zarys programu, „Problemy Zarządzania" 2013, nr 11/4, s. 11. 
się do słowa „wartość” w ujęciu aksjologicznym, czyli czegoś, co jest dobre, cenne lub też będące podstawą przyjętych w danej społeczności norm etycznych. W wielu koncepcjach tworzenia strategii marki powszechną praktyką jest wskazywanie wartości szczególnie cenionych przez twórców i użytkowników marki oraz traktowanie ich jako fundamentu tożsamości marki ${ }^{8}$. Drugi możliwy kontekst użycia pojęcia „wartość marki” odnosi się do zjawiska, które w literaturze anglojęzycznej określane jest mianem brand equity i które oznacza materialny i niematerialny kapitał marki ${ }^{9}$. Trzeci kontekst to wartość marki rozumiana po prostu jako jej wycena finansowa ${ }^{10}$. Wreszcie nie sposób też pominąć użycia tego terminu w kontekście roli marki w łańcuchu wartości, czyli jej udziału w procesie tworzenia i dostarczania wartości przez organizację swym interesariuszom ${ }^{11}$.

Przedmiotem badań w niniejszym artykule są wartości marki w pierwszym rozumieniu tego słowa, a zatem wartości tkwiące u podstaw strategii jej kreowania i rozwoju, będące filarem oraz rdzeniem jej tożsamości, a także spoiwem, łączącym jej twórców i użytkowników. Dla porządku w dalszej części artykułu wartości te nazywane będą wartościami strategicznymi. Termin ten będzie także używany w liczbie mnogiej, jako że w liczbie pojedynczej wyraz „wartość” rozumiany jest raczej jako wartość „czegoś”, natomiast w liczbie mnogiej zazwyczaj odnosi się właśnie do przekonań i zachowań społecznych ${ }^{12}$.

Jednocześnie w niniejszym artykule będzie stosowane pojęcie „wartości spajających" (ang. linking values). Zostało ono zaproponowane przez Bernarda Covę ${ }^{13}$ i zdefiniowane jako wkład danego produktu bądź usługi w tworzenie oraz wzmacnianie więzi pomiędzy jednostkami. Innymi słowy, wartości spajające stanowią łącznik, który z grupy ludzi czyni wspólnotę - w tym wypadku wspólnotę w formie społeczności marki. Termin ten będzie w artykule wykorzystywany zgodnie z założeniami koncepcji Bernarda Covy i - dla porządku - używany również w liczbie mnogiej.

\section{Rola wartości strategicznych marki}

Podstawową funkcją marki jest oznaczenie pochodzenia produktu. Patrząc z perspektywy nabywcy, można stwierdzić, że marka stanowi pewnego rodzaju obietnicę i gwarancję: zaspokojenia oczekiwań i uzyskania określonych rezultatów oraz

8 J. Kall, Silna marka. Istota i kreowanie, Polskie Wydawnictwo Ekonomiczne, Warszawa 2001, s. $24-41$.

9 K.L. Keller, Strategiczne zarządzanie marka, Oficyna Wolters Kluwer, Warszawa 2011, s. 53-57.

10 R. Shaw, Nowe spojrzenie na marketing, Wydawnictwo Studio Emka, Warszawa 2001, s. 119.

11 A.K. Koźmiński, D. Jemielniak, Zarządzanie od podstaw, Oficyna Wolters Kluwer, Warszawa 2011, s. 390-391.

12 J. Kreft, Za fasadą społeczności, Wydawnictwo Uniwersytetu Jagiellońskiego, Kraków 2015, s. 17.

13 B. Cova, Community and Consumption, „European Journal of Marketing” 1997, vol. 31, nr 3-4, s. 306-313. 
redukcji ryzyka związanego z zakupem; jednocześnie jest elementem, który upraszcza proces decyzyjny. Z punktu widzenia producenta głównymi funkcjami marki są odróżnienie oferowanego produktu od konkurencyjnych i ochrona prawna przed naśladowcami; dodatkowo marki są narzędziem umożliwiającym segmentację rynku i dostosowanie oferty do potrzeb poszczególnych grup odbiorców ${ }^{14}$.

Obok tych podstawowych funkcji marki, których wskazanie i zdefiniowanie nie stanowi większego problemu, istnieją też inne, dużo trudniejsze do uchwycenia, mające nienamacalny charakter, jednakże nie sposób ich nie dostrzec i zignorować ich znaczenie. To choćby funkcja symboliczna, wynikająca ze społecznego wymiaru konsumpcji, czy też funkcja transformacyjna, odnosząca się do zjawiska, jakim jest wpływ przekonań o marce na percepcję produktu i przeżycia związane z konsumpcją ${ }^{15}$. Wreszcie - jak pisze Jacek Kall - „marka tłumaczy sens i istotę oferty, dlaczego produkt istnieje, skąd pochodzi i dokąd zmierza" ${ }^{16}$. Funkcja ta jest bezpośrednio związana z obszarem strategicznego zarządzania marką w zakresie jej tożsamości.

$\mathrm{W}$ literaturze przedmiotu spotkać się można $\mathrm{z}$ wieloma propozycjami elementów, które składają się na tożsamość marki. Przykładowo w modelu zaproponowanym przez Lynna B. Upshawa ${ }^{17}$ są nimi przede wszystkim pozycjonowanie marki oraz typ jej osobowości, zaś centralnym punktem jest tzw. esencja marki oraz główne wartości ją definiujące. $Z$ kolei według koncepcji Interbrand elementami tworzącymi strukturę marki są: wizja, misja, wartości kluczowe, funkcjonalne i ekspresyjne, obszar kompetencji, atrybuty, produkty i sygnały marki ${ }^{18}$. Jean-Noël Kapferer ${ }^{19}$ sugeruje natomiast, aby w definiowaniu tożsamości marki odpowiadać na następujące pytania:

- jaka jest wizja i cel marki?

- co wyróżnia markę?

- jakie potrzeby zaspokaja marka?

- co w marce jest niezmiennego, jaka jest jej trwała natura?

- jaka przyświeca jej wartość lub wartości?

- jaki jest obszar kompetencji marki?

- jakie znaki czynią markę rozpoznawalną?

Jak zatem widać już na tych kilku przykładach, wartości stanowią ważny element budujący tożsamość marki. Według Kalla ${ }^{20}$ są one wręcz emanacją tożsamości marki. Kapfere ${ }^{21} \mathrm{z}$ kolei podkreśla, że wartości centralne marki powinny być znane wszystkim pracownikom firmy i wszystkim osobom zaangażowanym w rozwój marki, a także przejawiać się w produktach, usługach oraz komunikacji.

14 J. Kall, dz. cyt., s. 15-24.

15 Tamże, s. 20.

16 Tamże, s. 16.

17 L.B. Upshaw, Building Brand Identity, John Wiley \& Sons, New York 1995, s. 24.

18 J. Kall, dz. cyt., s. 26.

19 J.N. Kapferer, The New Strategic Brand Management, Kogan Page, London-Philadelphia 2008, s. 172.

20 J. Kall, dz. cyt., s. 34 .

21 J.N. Kapferer, dz. cyt., s. 273. 
Wartości strategiczne określają to, co jest dla danej marki najważniejsze. Definiują ją i określają kierunek jej rozwoju od ogólnych założeń strategicznych po najdrobniejsze działania taktyczne. Łączą właścicieli, twórców i osoby zarządzające marką - z nabywcami. Są także czymś, co zapewnia marce ciągłość w czasie, powinny być bowiem uniwersalne i niezależne od zmian $\mathrm{w}$ otoczeniu zewnętrznym (np. nowe technologie, nowi konkurenci) i wewnętrznym (np. nowe produkty, zmieniające się koncepcje komunikacji na poziomie taktycznym). Jest to szczególnie istotne, jeśli wziąć pod uwagę, że konsekwencja i wewnętrzna spójność są podstawowym źródłem wiarygodności każdej marki.

Wartości strategiczne marki nie zawsze są wyrażone wprost. Często można je wyczytać z misji lub wizji marki lub też elementów określanych jako esencja czy wręcz dusza marki ${ }^{22}$. Nierzadko też $\mathrm{w}$ strategiach marketingowych zawierają się one w tzw. propozycji wartości (ang. value proposition), oznaczającej zbiór korzyści, jakie marka oferuje swoim klientom w celu zaspokojenia ich potrzeb ${ }^{23}$. Nie brakuje też przypadków, w których o wartościach strategicznych danej marki można wnioskować po prostu na podstawie działań taktycznych (np. cech produktów, komunikatów reklamowych, procesów wewnętrznych działań PR czy CSR).

I tak na przykład marka Virgin komunikuje swoje wartości strategiczne wprost. Są nimi: zabawa, korzystny stosunek jakości do ceny, jakość, innowacyjność, podejmowanie wyzwań i znakomita obsługa klienta ${ }^{24}$. Misja marki Harley-Davidson brzmi: „Jechać i dobrze się bawić" (ang. To Ride and Have Fun) i jest to motto łączące tysiące jej użytkowników na świecie ${ }^{25}$. W przypadku marki Benetton wartości strategiczne emanują z jej esencji, która jest zdefiniowana jako „kolor”. Wyraża się ona nie tylko funkcjonalnie w barwach ubrań tego producenta, ale też symbolicznie - w komunikowanej przez markę wizji świata społecznego, w której wszystkie kolory współżyją w harmonii $^{26}$. Natomiast jeśli wziąć pod lupę działania marki The Body Shop - od naturalnego składu produktów i opakowań nadających się do recyklingu, przez politykę surowcową, aż po akcje społeczne i działania PR - nietrudno wywnioskować, że wartościami strategicznymi, jakimi kieruje się ta marka, jest dbanie o siebie i środowisko naturalne ${ }^{27}$.

\section{Rola wartości spajającej w budowaniu wspólnoty wokół marki}

Z kwestią tożsamości marki, a tym samym jej wartości strategicznych, nieodłącznie wiąże się pytanie o zakres kontroli osób zarządzających marką nad tym, w jaki sposób jest ona postrzegana przez odbiorców. W większości ujęć teoretycznych, a także

22 J. Kall, dz. cyt., s. 39.

23 P. Kotler, G. Armstrong, Principles of Marketing, Person Education Limited, Harlow 2018, s. 35.

24 J.N. Kapferer, dz. cyt., s. 273.

25 K.L. Keller, dz. cyt., s. 90.

26 J. Kall, dz. cyt., s. 34.

27 K.L. Keller, dz. cyt., s. 74. 
wśród praktyków brandingu zwykło się przyjmować, że jeśli mowa jest o tożsamości marki, mamy na myśli zamierzenia twórców i idealną wizję marki zapisaną w strategii, natomiast jeśli mowa o wizerunku, to odnosi się on do obrazu marki w umysłach nabywców ${ }^{28}$. Wizerunek ten da się celowo kształtować poprzez wywoływanie u odbiorców określonych reakcji i postaw ${ }^{29}$, jednak trzeba mieć świadomość, że o ile można mieć pełnię kontroli nad procesem tworzenia tożsamości marki, o tyle wpływ osób zarządzających marką na to, jak jest ona postrzegana, jest ograniczony i uwarunkowany wieloma czynnikami zewnętrznymi.

Jednocześnie granica pomiędzy tożsamością a wizerunkiem jest płynna, a wiele elementów składających się na tożsamość marki pokrywa się z elementami wizerunku lub też kształtuje się na ich styku. Przykładowo pozycjonowanie marki jest zarówno założeniem strategicznym twórców, dotyczącym cech mających wyróżniać markę na rynku, jak i wynikiem postrzegania marki przez nabywców w relacji do marek konkurencyjnych. Podobnie jest $\mathrm{z}$ wartościami, które umiejscowić można na styku relacji pomiędzy marką a odbiorcą. We wspomnianym już wcześniej ujęciu struktury marki według Interbrand wartości kluczowe są nawet rozumiane jako „to, co łączy konsumenta i markę na poziomie podstawowym - filozofia, moralność, zachowanie" 30 .

Wartości jako tego typu łącznik odgrywają także znaczącą rolę w powstawaniu wspólnoty marki. Jacek Pogorzelski ${ }^{31}$ uważa, że centralną koncepcją brandingu społecznego, czyli strategii budowania marki opartej na więzi społecznej, są tzw. wartości spajające wspólnotę (ang. linking values). Warto jednak przy tym zauważyć, że wartości te rzadko osadzone są w funkcjonalnych cechach produktów i usług. Stanowią one natomiast coś tak ważnego i cenionego przez nabywców, że motywują ich do działania na rzecz celebrowania, rozwijania, praktykowania czy wręcz obrony tej wartości w ramach wspólnoty ${ }^{32}$. „To, co w największym stopniu spaja plemię i społeczność, to poczucie łączności z osobami, które dogłębnie się rozumieją" - pisze Pogorzelski ${ }^{33}$. Autor ten podkreśla też, że członkowie takich grup aktywnie poszukują wartości wzmacniających więzy wspólnotowe, ponieważ ważne jest dla nich trwanie wspólnoty, a także emocje związane z silnymi doświadczeniami wspólnotowymi. Co więcej, aby zaproponowane przez markę wartości strategiczne miały szansę stać się wartościami spajającymi wspólnotę, muszą być silne $\mathrm{w}$ takim stopniu, aby motywowały do zaangażowania, a wręcz poświęcenia: $\mathrm{w}$ formie czasu, pieniędzy, wysiłku, a czasem nawet walki.

28 J. Kall, dz. cyt., s. 24-25.

29 A.K. Koźmiński, D. Jemielniak, dz. cyt., s. 299.

30 J. Kall, dz. cyt., s. 26.

31 J. Pogorzelski, Marka na cztery sposoby, Oficyna Wolters Kluwer, Warszawa 2015, s. 168.

32 B. Cova, V. Cova, Tribal Marketing, „European Journal of Marketing” 2001, wydanie specjalne: Societal Marketing in 2001 and Beyond, s. 10.

33 J. Pogorzelski, dz. cyt., s. 137. 


\section{Wartości strategiczne marki a wartości spajające wspólnotę}

Pytanie, które w tym miejscu wydaje się fundamentalne, brzmi: czy wartości spajające wspólnotę powstałą wokół marki muszą być tymi samymi wartościami, które zostały wpisane w strategię marki przez jej twórców?

Pogorzelski ${ }^{34}$ pisze, że

(...) wartość spajająca często nie jest do zaplanowania w klasycznym marketingowym procesie, lecz stanowi efekt autonomicznego nadawania znaczenia wewnątrz wspólnoty. Nie można tak po prostu zaproponować pakietu „produkt + idea”, ponieważ i tak produkt zostanie poddany interpretacji, a narzucona z zewnątrz idea nie będzie ideą wspólnoty.

Zdaniem tego autora rolą twórców i osób zarządzających marką jest raczej wspieranie i wspomaganie wartości spajającej wspólnotę niż podsuwanie ludziom gotowca. Wspólnoty, nawet jeśli tworzą się wokół pewnych marek, pozostają autonomiczne, a ich członkowie nie są jedynie pasywnymi odbiorcami, lecz aktywnymi uczestnikami procesu tworzenia wizerunku marki, jej współtwórcami. „Jeżeli jej [wspólnoty - przyp. A.M.-G.] członkowie dostrzegą możliwość wykorzystania marki, zrobią to. Jeżeli jednak nie dojrzą w niej niczego, co pozwoli im zrealizować własne cele, żadna perswazja nie zmusi ich do włączenia marki w orbitę swoich zainteresowań" - uważa Pogorzelski ${ }^{35}$.

$\mathrm{Na}$ problem ten spojrzeć można też z perspektywy zarządzania mediami. Współcześnie organizacje, dysponując własnymi mediami (strony internetowe, blogi, kanały społecznościowe, nowe narzędzia komunikacji z klientami) i tworząc własne treści, wchodzą $\mathrm{w}$ rolę wydawców ${ }^{36}$. Jednocześnie użytkownicy mediów przestają być biernymi odbiorcami komunikatów, lecz są aktywnymi współtwórcami treści, znaczeń i doświadczeń. W związku z tym marki stają dziś przed podobnymi wyzwaniami, jak firmy medialne, tj. przestają być autonomiczne w produkcji, działaniach marketingowych i kontroli nad kanałami dystrybucji. Menedżerowie muszą w związku z tym zaakceptować aktywną i niezależną rolę odbiorców oraz brak możliwości sprawowania pełnej kontroli nad ich działaniami ${ }^{37}$.

Z punktu widzenia osób zarządzających marką sytuacją najbardziej pożądaną jest, kiedy zaproponowane przez twórców marki wartości strategiczne stają się automatycznie wartościami spajającymi wspólnotę, w praktyce jednak zdarza się to niezwykle rzadko. Wartości strategiczne mogą być nie tylko reinterpretowane przez odbiorców; mogą też oni stworzyć społeczność alternatywną wobec marki lub społeczność przeciw marce. Bernard Cova, Robert Kozinets i Avi Shankar ${ }^{38}$ w książce Consumer

34 Tamże, s. 169.

35 Tamże, s. 137.

36 Brand as Publishers, https://deloitte.wsj.com/cmo/2016/12/12/brand-as-publisher/ (dostęp: 6.12.2019).

37 J. Kreft, Za fasada..., s. 133.

38 B. Cova, R.V. Kozinets, A. Shankar, Tribes, Inc.: The New World of Tribalism, [w:] tychże (red.), Consumer Tribes, Elsevier, Oxford 2007, s. 6-20. 
Tribes wyróżniają cztery typy wspólnot: aktywatorów (ang. activators), przedsiębiorców (ang. entrepreneurs), podwójnych agentów (ang. double agents) oraz plądrowników (ang. plunderers). Tylko ci pierwsi - aktywatorzy - przyjmują wartości marki, aktywując wspólnotę. Przedsiębiorcy przyjmują rolę zaangażowanych współtwórców marek na polu społecznym, kulturowym i ekonomicznym. Podwójni agenci z jednej strony przyjmują interesujące ich oferty marek, ale z drugiej strony nie mają oporów, by przekształcać ich znaczenie. Z kolei plądrownicy w pewien sposób zawłaszczają sobie marki i nierzadko podejmują działania sprzeczne z zamierzeniami ich twórców bądź właścicieli.

Inny autor, Alex Wipperfürth, ukuł nawet nazwę dla takiego zjawiska: brand hijack, które na język polski przetłumaczyć można jako porwanie marki. W swojej książce Brand hijack: marketing bez marketingu sugeruje jednak, aby ze zjawiskiem tym nie walczyć, lecz zaakceptować możliwość jego wystąpienia, czy wręcz uwzględnić je w strategii marki. Jak pisze Wipperfürth:

Menedżerowie zajmujący się marketingiem stracili kontrolę. Przejęli ją konsumenci. Na całym świecie wnikliwi, zaangażowani i kreatywni ludzie pomagają opracować i zapewnić przychylne przyjęcie produktom i usługom - niekiedy nawet bez akceptacji samej firmy. (...) W porwaniu marki chodzi o to, aby pozwolić konsumentom (i wszystkim innym interesariuszom) kształtować znaczenie marki i zachęcać do niej innych ${ }^{39}$.

Podsumowując zatem, należałoby przyjąć, że rola wartości w budowaniu wspólnoty wokół marki jest fundamentalna, przy czym główne wartości strategiczne przyjęte odgórnie przez markę wcale nie muszą pokrywać się z tym, co definiowane jest przez daną wspólnotę jako wartość spajająca. Co jednak szczególnie ważne, jeśli nawet wystąpi taka rozbieżność, nie musi to być zjawisko o negatywnych konsekwencjach dla marki. Wprost przeciwnie - zgoda na współtworzenie przez odbiorców znaczenia marki i współpraca z nimi w obszarze definiowania wartości strategicznych marki może służyć jej wzmocnieniu i rozwojowi.

\section{Wartości strategiczne marki versus wartości spajające wspólnotę. Analiza marki IKEA i społeczności IKEAhackers}

IKEA to jedna z najbardziej znanych globalnych marek - według stanu z roku 2017 była obecna w $29 \mathrm{krajach}^{40}$. Jest też jedną z najcenniejszych marek na świecie w rankingu Interbrand za 2018 rok uplasowała się na 27 miejscu z wyceną w wysokości 17,458 miliarda dolarów ${ }^{41}$.

39 A. Wipperfürth, Brand hijack, czyli marketing bez marketingu, Wydawnictwo One Press, Gliwice 2010, s. 13-14.

40 Na podstawie informacji ze strony: https://www.ikea.com/ms/pl_PL/this-is-ikea/about-the-ikea-group/index.html (dostęp: 3.11.2019).

${ }^{41} \mathrm{Na}$ podstawie informacji ze strony: https://www.interbrand.com/best-brands/ best-global-brands/2018/ranking/ (dostęp: 3.11.2019). 
Firmę IKEA założył w 1943 roku Szwed, Ingvar Kamprad, sprzedając początkowo drobne produkty, takie jak portfele czy długopisy. Z czasem stała się ona jednym $z$ największych na świecie producentów mebli i jednocześnie siecią sklepów meblowych o tej samej nazwie. Celem tego artykułu jest analiza relacji pomiędzy strategicznymi wartościami marki IKEA a wartościami spajającymi społeczność IKEAhackers.

W 2006 roku Malezyjka Jules Yap założyła blog Ikeahackers.net (początkowo pod adresem ikeahacker.blogspot.com). Ideą strony było zamieszczanie na niej kreatywnych przeróbek produktów IKEA - zarówno tych tworzonych przez nią samą, jak i znalezionych w sieci. Blog zyskał popularność wśród użytkowników na całym świecie, którzy nadsyłali zdjęcia zhakowanych, czyli zmodyfikowanych wedle własnego pomysłu mebli IKEA ${ }^{42}$.

Po ośmiu latach od założenia bloga Jules Yap otrzymała list od IKEA z zarzutami naruszenia własności intelektualnej - konkretnie chodziło o wykorzystanie nazwy marki w nazwie IKEAhackers. Przedstawiciele firmy żądali przekazania im domeny ikeahackers.net. Ostatecznie, po kilku miesiącach negocjacji, IKEA zgodziła się na dalsze prowadzenie bloga przez Malezyjkę pod tym adresem, jednakże pod warunkiem, że będzie to działalność niekomercyjna. Dla autorki oznaczało to rezygnację $\mathrm{z}$ reklam i jakichkolwiek innych dochodów $\mathrm{z}$ tytułu prowadzenia strony $^{43}$.

Podjęte przez IKEA kroki wzburzyły społeczność IKEAhackers, której członkowie masowo zaczęli wysyłać do firmy maile oraz krytykować w sieci jej działania. Fala niezadowolenia sprawiła, że w ciągu zaledwie kilku dni przedstawiciele marki zmienili swoje stanowisko i wycofali się ze wszystkich żądań. W oficjalnej komunikacji wyrażali żal z powodu zaistniałej sytuacji, przekonując, że nigdy nie było ich intencją, by zlikwidować stronę IKEAhackers.net, oraz że doceniają zainteresowanie członków społeczności IKEAhackers produktami marki IKEA ${ }^{44}$.

Obecnie relacje pomiędzy marką IKEA a założycielką bloga oraz społecznością IKEAhackers budowane są w duchu współpracy. Przykładowo w 2018 roku w muzeum IKEA w Älmhult otwarto wystawę poświęconą zjawisku i sztuce hakowania produktów firmy ${ }^{45}$. Warto też przy tym dodać, że społeczność IKEAhackers tworzą obecnie nie tylko osoby skupione wokół bloga Jules Yap, lecz dużo szersze grono hakerów, przerabiających produkty IKEA i publikujących rezultaty swej twórczości na innych stronach internetowych, blogach i w mediach społecznościowych.

42 Na podstawie informacji ze strony: https://www.ikeahackers.net/about (dostęp: 3.11.2019).

${ }_{43} \mathrm{Na}$ podstawie informacji ze strony: https://www.ikeahackers.net/2014/06/big-changes-coming-to-ikeahackers.html (dostęp: 3.11.2019).

$44 \mathrm{Na}$ podstawie informacji ze strony: https://www.ikeahackers.net/2014/06/ inter-ikea-systems-bv-called-me.html (dostęp: 3.11.2019).

${ }_{45}$ Na podstawie informacji ze strony: https://www.ikea.com/au/en/ideas/ikea-hacks/ (dostęp: 3.11.2019). 


\section{Wartości strategiczne marki IKEA}

Choć na stronach internetowych IKEA wartości strategiczne marki nie są nigdzie wyrażone wprost, można o nich wnioskować na podstawie zapisów o misji i wizji, a także wartości deklarowanych przez organizację oraz komunikacji skierowanej do klientów.

Na polskojęzycznej wersji witryny IKEA (ikea.com), w artykule zatytułowanym Nasza wizja i idea biznesowa, czytamy:

Wizją IKEA jest tworzenie lepszych warunków codziennego życia dla wielu ludzi. Naszą ideą biznesową jest oferowanie szerokiego asortymentu funkcjonalnych i dobrze zaprojektowanych artykułów wyposażenia domu, w cenach tak niskich, by jak najwięcej ludzi mogło sobie na nie pozwolićc ${ }^{46}$.

Jednocześnie na stronie korporacyjnej (industry.ikea.pl), skierowanej do osób zainteresowanych pracą $\mathrm{w}$ tej firmie, założenia wizji uzupełniono także o misję oraz listę wartości ważnych dla organizacjii ${ }^{47}$ :

Misją IKEA Industry jest tworzenie wyjątkowej wartości dla Klienta poprzez rozwój mocy produkcyjnych, będących naszą unikalną przewagą konkurencyjną. Razem - wnosimy wkład w cały łańcuch wartości, zapewniając wiedzę o produkcji i będąc dobrym przykładem we wszystkich aspektach biznesu.

Wspólnie wyznawane wartości i kultura sprawiają, że IKEA jest tak wyjątkowa. We wszystkich jednostkach na całym świecie można spotkać współpracowników, którzy podzielają te same przekonania.

Owe wartości to - jak czytamy dalej - poczucie wspólnoty, troska o ludzi i planetę, świadomość kosztów, prostota, poszukiwanie ulepszeń i nowych rozwiązań, nieszablonowe myślenie, dawanie i branie odpowiedzialności oraz przywództwo poprzez przykład. W tym miejscu trzeba uczynić jednak zastrzeżenie, że są to wartości organizacji, a nie wartości strategiczne marki, jakkolwiek można domniemywać, że te ostatnie są z nimi spójne.

Sztandarowym hasłem, jakie wielokrotnie pojawia się w komunikacji marki skierowanej do klientów, jest tzw. demokratyczne wzornictwo. Termin ten łączy w sobie takie wartości, jak funkcjonalność, forma i jakość produktów z jednej strony oraz ich dostępność dla nabywców (przede wszystkim cenową) z drugiej. Demokratyczne wzornictwo przekłada się na tworzenie rozwiązań dla przeciętnych użytkowników: zwykłych ludzi i ich rodzin. Produkty IKEA mają ułatwiać codzienne, domowe życie $\mathrm{z}$ dziećmi, nierzadko w małych przestrzeniach mieszkalnych. Idea demokratycznego wzornictwa w dużej mierze wynika z dziedzictwa marki i historii jej założyciela. Ingvar Kamprad wychował się w szwedzkiej Smålandii - surowym,

46 Na podstawie informacji ze strony: https://www.ikea.com/ms/pl_PL/about-the-ikea-group/ company-information/ (dostęp: 3.11.2019).

${ }_{47}$ Na podstawie informacji ze strony: https://www.industry.ikea.pl/index/o-nas/kultura-i-wartosci/ (dostęp: 3.11.2019). 
kamienistym, a przez to biednym regionie. Takie warunki zmuszały mieszkańców do oszczędności i pomysłowości, a także - jak czytamy na stronach internetowych firmy - do rozwiązywania codziennych problemów według zasady „żadnych głupot”48. IKEA, zgodnie z deklaracją „People and Planet Positive”, podkreśla także swoją dbałość o ludzi i środowisko naturalne.

Zdaniem Jacka Pogorzelskiego ${ }^{49}$ analiza marki IKEA z wykorzystaniem narzędzia, jakim jest molekuła marki Granta, pozwala odnaleźć w niej następujące przejawy idei kulturowych (idee kulturowe również mogą odwoływać się do wartości): ekologia, naturalność, prostota, katalog, samodzielne złożenie, dobra wartość za cenę, sklepy labirynty, aranżacje jako inspiracje, świadomy styl życia, a także skandynawskie wzornictwo. Na tej podstawie autor wnioskuje, że nadrzędną ideę marki IKEA można zdefiniować jako wydajność - rozumianą z jednej strony jako stricte funkcjonalna, $\mathrm{z}$ drugiej jako związana $\mathrm{z}$ tendencją do poszukiwania racjonalnych skrótów w dochodzeniu do celu.

Podsumowując powyższe, należy stwierdzić, że w tej analizie za wartości strategiczne marki IKEA zostały uznane:

- wydajność (świadomość kosztów połączona z poszukiwaniem ulepszeń i nowych rozwiązań);

- funkcjonalność;

- prostota;

- pomysłowość (nieszablonowe myślenie);

- demokratyczne wzornictwo (dostępność dla każdego);

- ekologiczność (troska o środowisko);

- troska o ludzi (poczucie wspólnoty, odpowiedzialność, przywództwo przez przykład).

\section{Wartości spajające społeczność IKEAhackers}

Społeczność IKEAhackers wpisuje się w dużo szerszy ruch DIY - z angielskiego Do It Yourself - czyli „zrób to sam”. Skupia on ludzi, którzy samodzielnie i amatorsko wykonują różne prace - może to być rękodzieło, krawiectwo, prace remontowe, majsterkowanie czy też, jak w omawianym przykładzie, przerabianie mebli. W ostatnich latach zjawisko to przybrało na sile i zaczęło przeżywać rozkwit. Przyczynił się do tego rozwój Internetu, umożliwiając ludziom znacznie szersze możliwości dzielenia się wiedzą na wszelkiego rodzaju stronach i forach internetowych. Do wartości, jakie łączą osoby działające w nurcie DIY, zaliczyć można między innymi: chęć wyróżnienia się i podkreślenia swojej wyjątkowości poprzez posiadanie

48 Na podstawie informacji ze strony: https://www.ikea.com/ms/pl_PL/this-is-ikea/the-ikea-concept/index.html (dostęp: 3.11.2019).

49 J. Pogorzelski, dz. cyt., s. 208. 
unikatowych rzeczy, satysfakcję z tworzenia czegoś samodzielnie i poczucie samorealizacji, ale też oszczędność czy ekologiczny styl życia ${ }^{50}$.

Przestrzenią, dzięki której zrodził się (czy raczej został nazwany i zdefiniowany) ruch IKEAhackers, stał się blog Jules Yap. Daniela Rosner i Jonathan Bean ${ }^{51}$ przeprowadzili pogłębione wywiady z przedstawicielami tej społeczności, pytając ich między innymi o to, dlaczego przerabiają produkty IKEA, na czym ich zdaniem polega idea hakowania, kim według nich jest haker, co ich motywuje do hakowania produktów IKEA i jakie znaczenie ma dla nich funkcjonowanie w szerszej społeczności, w tym dzielenie się wiedzą i rezultatami swej pracy.

Wśród odpowiedzi na pytania o motywację badani najczęściej wskazywali satysfakcję, jaką daje im proces twórczy: od projektowania nowych rozwiązań po samodzielne ich wykonywanie. Przedstawiciele społeczności w wywiadach podkreślali, że cenią oni produkty IKEA głównie za ich funkcjonalność, przy czym jednocześnie przeszkadza im ogromne ich rozpowszechnienie - w domach na całym świecie można bowiem spotkać dokładnie te same meble. Hakowanie jest dla nich sposobem na przeciwstawienie się tej standaryzacji poprzez stworzenie czegoś oryginalnego, niepowtarzalnego i osobistego. Fakt, że meble te są tanie, sprawia, iż nie postrzegają ich jako czegoś cennego, ale jako łatwo dostępny (i to w dowolnym miejscu na świecie) surowiec do własnej twórczości. W przeróbkach liczy się przede wszystkim funkcjonalność, pomysłowość i dostosowanie produktów do indywidualnych potrzeb użytkowników. Część badanych (choć nie wszyscy) ceni sobie także funkcjonowanie w szerszej społeczności, w której mogą dzielić się wiedzą i doświadczeniami. Dla niektórych hakowanie mebli IKEA jest też sposobem wyrażenia siebie i szansą na bycie dostrzeżonym w przestrzeni publicznej.

Analizując powyższe, można określić wartości spajające społeczność IKEAhackers, a następnie - w zestawieniu z wymienionymi wcześniej wartościami marki IKEA - wskazać te wartości marki, które zostały przez społeczność przyjęte, zreinterpretowane oraz dodane (zob. tabela 1 ).

Za wartości, które jednocześnie są strategiczne z punktu widzenia marki IKEA oraz pełnią funkcję spajającą społeczność IKEAhackers, uznać można wydajność, funkcjonalność, pomysłowość.

W przypadku prostoty i demokratycznego wzornictwa, a także troski o ludzi mamy do czynienia z reinterpetacją znaczenia przez społeczność. Dla IKEA prostota jest wspólną cechą produktów, która pozwala przedsiębiorstwu osiągać określone cele (np. utrzymanie niskich kosztów, masowa produkcja, łatwość montażu). Dla hakerów natomiast liczy się przede wszystkim to, że dzięki swej prostocie meble IKEA mogą być traktowane jako surowiec. Podobna reinterpretacja zachodzi

50 A. Mardosz-Grabowska, Pokolenie Do It Yourself, https://questus.pl/blog/do-it-yourself/ (dostęp: 3.11.2019).

51 D. Rosner, J. Bean, Learning from IKEA Hacking: "I'm Not One to Decoupage a Tabletop and Call It a Day", materiały z konferencji SIGCHI Conference on Human Factors in Computing Systems (Boston, USA, 4-9 kwietnia 2009). 
Tabela 1. Stosunek społeczności IKEAhackers do wartości strategicznych marki IKEA

\begin{tabular}{|c|c|c|}
\hline $\begin{array}{l}\text { Wartości przyjęte } \\
\text { przez społeczność }\end{array}$ & $\begin{array}{l}\text { Wartości zreinterpretowane } \\
\text { przez społeczność }\end{array}$ & $\begin{array}{l}\text { Wartości dodane } \\
\text { przez społeczność }\end{array}$ \\
\hline $\begin{array}{l}\text { wydajność } \\
\text { funkcjonalność } \\
\text { pomysłowość }\end{array}$ & $\begin{array}{l}\text { prostota } \\
\text { demokratyczne wzornictwo } \\
\text { IKEA: } \\
\text { - proste projekty, } \\
\text { demokratyczne produkty, dla każdego, w przy- } \\
\text { stępnych cenach. } \\
\text { IKEAhackers: } \\
\text { - prosty surowiec dostępny wszędzie na świecie } \\
\text { w takiej samej formie, } \\
\text { - demokratyczny surowiec dla każdego twórcy. } \\
\text { Troska o ludzi } \\
\text { IKEA: poczucie wspólnoty i odpowiedzialności za } \\
\text { ludzi, przywództwo } \\
\text { IKEAhackers: współpraca w ramach społeczności }\end{array}$ & $\begin{array}{l}\text { satysfakcja } \mathrm{z} \text { własnej } \\
\text { twórczości } \\
\text { unikatowość (w kontrze } \\
\text { do standaryzacji) } \\
\text { sposób wyrażania siebie }\end{array}$ \\
\hline
\end{tabular}

Źródło: opracowanie własne.

w przypadku wartości, jaką jest demokratyczne wzornictwo. O ile bowiem w strategię marki wpisane jest projektowanie produktów dostępnych (głównie cenowo) dla każdego konsumenta, o tyle dla hakerów liczy się dostępność surowca (niski koszt, globalna dystrybucja, identyczna forma) do własnej pracy twórczej.

Za wartość zreinterpretowaną przez społeczność została uznana także troska o ludzi. Z perspektywy IKEA wyraża się ona przede wszystkim w dbałości oraz poczuciu odpowiedzialności za pracowników i klientów, a także przyjęciu pozycji lidera, natomiast z punktu widzenia członków IKEAhackers wartością jest współpraca w ramach społeczności oraz relacje o charakterze partnerskim.

Obok wartości wspólnych dla strategii marki i społeczności, wskazać można także wartości, które nie mają znaczenia z punktu widzenia strategii marki IKEA, ale stanowią ważny element spajający wspólnotę. Są to: satysfakcja z własnej twórczości, unikatowość i sposób wyrażania siebie.

Warto też zwrócić uwagę, że w powyższej analizie nie znalazły się wartości strategiczne marki, które określić by można jako odrzucane przez społeczność. Choć przedstawiciele IKEAhackers prezentują niechęć względem standaryzacji, jednak trudno mówić o odrzuceniu w sytuacji, w której standaryzacja nie stanowi wartości strategicznej dla marki, jest ona bowiem wynikiem działań w imię innych wartości (demokratyzacja), a nie wartością samą w sobie. Z punktu widzenia społeczności głównej roli nie odrywa także ekologiczność, przy czym tutaj również mamy do czynienia nie z odrzuceniem przez wspólnotę wartości strategicznej marki, a jedynie z niepełnieniem przez nią funkcji wartości spajającej. 
Przyjmując typologię zaproponowaną przez Covę, Kozinetsa i Shankara ${ }^{52}$, społeczność IKEAhackers można zatem uznać za najbliższą podwójnym agentom, którzy z jednej strony przyjmują interesujące ich wartości marek, ale $\mathrm{z}$ drugiej przekształcają ich znaczenie wedle własnych potrzeb lub też - jak to się dzieje w tym przypadku - dodają do nich wartości uznane przez siebie za równie istotne. Oznacza to, że propozycja marki (wartości strategiczne) jest kluczowa w procesie formowania się społeczności, ale nie jest też wystarczająca ani dla jej powstania, ani dla rozwoju. Od osób zarządzających marką taka sytuacja wymaga zaakceptowania faktu, że członkowie społeczności nie będą jedynie biernymi odbiorcami, lecz mogą wejść w rolę aktywnych kreatorów znaczenia marki.

\section{Podsumowanie i wnioski końcowe}

Studium przypadku marki IKEA i IKEAhackers pokazuje, że społeczności - nawet takie, które z pozoru można by uznać za grupy fanów - nie muszą wyznawać tych samych wartości co marka. Uwidacznia się to szczególnie w sytuacji konfliktu wartości. Przykład ten potwierdza, że społeczności są autonomiczne i nie poddają się zarządzaniu ani kontroli ze strony marek, a wartości strategiczne marki nie są przez społeczność ani automatycznie, ani bezkrytycznie przyjmowane jako wartości spajające. W tej konkretnej sytuacji przedstawiciele marki IKEA zaakceptowali to dopiero $\mathrm{w}$ obliczu realnej groźby kryzysu wizerunkowego, związanego z masowym sprzeciwem członków ruchu IKEAhackers wobec działań firmy.

Omawiany przypadek nie tylko jest interesującym materiałem do analizy relacji pomiędzy marką a wspólnotą, ale też ukazuje rolę, jaką wirtualne wspólnoty zaczynają odgrywać w życiu współczesnych konsumentów. Przynależność do takich grup może być sposobem zaspokajania różnego rodzaju potrzeb: od poczucia wspólnoty i integracji z grupą, po zamanifestowanie swej tożsamości i dążenie do samorealizacji. Tu rodzi się jednak pytanie, jak duży wpływ społeczności konsumenckie mogą mieć na swoich członków, choćby w zakresie przyjmowanych przez nich postaw czy podejmowanych decyzji konsumenckich. Obszar ten z pewnością może stać się przedmiotem dalszych badań.

Mając natomiast na uwadze cel, jakim jest budowanie marek opartych na więzi społecznej, można stwierdzić, że wiele wnieść mogłyby badania porównawcze między społecznościami, które w różnym zakresie przyjęły, przekształciły bądź odrzuciły wartości strategiczne marek, wokół których wyrosły. Dzięki temu możliwe mogłoby być postawienie i zweryfikowanie hipotez dotyczących warunków, w jakich wartości strategiczne marki mogą stać się wartościami spajającymi społeczność, a w jakich dochodzi do przekształcenia ich bądź odrzucenia przez społeczność.

52 B. Cova, R.V. Kozinets, A. Shankar, Tribes, Inc..., s. 6-20. 


\section{Bibliografia}

Brand as Publishers, https://deloitte.wsj.com/cmo/2016/12/12/brand-as-publisher/ (dostęp: 6.12.2019).

Canniford R., A Typology of Consumption Communities, [w:] R.W. Belk i in. (red.), Research in Consumer Behavior, Emerald Publishing, Bigley 2011, s. 57-75.

Cova B., Community and Consumption, „European Journal of Marketing” 1997, vol. 31, nr 3-4, s. $297-316$.

Cova B., Cova V., Tribal Marketing: The Tribalisation of Society and Its Impact on the Conduct of Marketing, „European Journal of Marketing”, 2002, wydanie specjalne: Societal Marketing in 2002 and Beyond.

Cova B., Kozinets R.V., Shankar A., Tribes, Inc.: The New World of Tribalism, [w:] tychże (red.), Consumer Tribes, Elsevier, Oxford 2007.

Kall J., Silna marka. Istota i kreowanie, Polskie Wydawnictwo Ekonomiczne, Warszawa 2001.

Kapferer J.-N., The New Strategic Brand Management, Kogan Page, London-Philadelphia 2008.

Keller K.L., Strategiczne zarządzanie marka, Oficyna Wolters Kluwer, Warszawa 2011.

Kociatkiewicz J., Kostera M., Zarządzanie humanistyczne. Zarys programu, „Problemy Zarządzania” 2013, nr 11/4, s. 9-19.

Kotler P., Armstrong G., Principles of Marketing, Person Education Limited, Harlow 2018.

Koźmiński A.K., Jemielniak D., Zarządzanie od podstaw, Oficyna Wolters Kluwer, Warszawa 2011.

Kreft J., Za fasadą społeczności, Wydawnictwo Uniwersytetu Jagiellońskiego, Kraków 2015.

Kreft J., Zarządzanie współtworzeniem wartości w mediach. Od łańcucha do konstelacji, „Problemy Zarządzania” 2013, nr 11/4, s. 160-171.

Mardosz-Grabowska A., Pokolenie Do It Yourself, https://questus.pl/blog/do-it-yourself/ (dostęp: 3.11.2019).

Muñiz A., O'Guinn T., Brand Community, „Journal of Consumer Research” 2001, vol. 27, nr 4, s. $412-432$.

Muñiz A., O'Guinn T., Marketing Communications in a World of Consumption and Brand Communities, [w:] A.J. Kimmel (red.), Marketing Communication: New Approaches, Technologies, and Styles, Oxford University Press, Oxford 2005, s. 65-66.

Pogorzelski J., Marka na cztery sposoby, Oficyna Wolters Kluwer, Warszawa 2015.

Rheingold H., The Virtual Community, https:/www.rheingold.com/vc/book/ (dostęp: 3.11.2019).

Rosner D., Bean J., Learning from IKEA Hacking: "I'm Not One to Decoupage a Tabletop and Call It a Day", materiały z konferencji SIGCHI Conference on Human Factors in Computing Systems (Boston, USA, 4-9 kwietnia 2009).

Shaw R., Nowe spojrzenie na marketing, Wydawnictwo Studio Emka, Warszawa 2001.

Siuda P., Wpływ Internetu na rozwój fandomów, czyli o tym, jak elektroniczna sieć rozwija i popularyzuje społeczności fanów, [w:] M. Sokołowski (red.), Media i społeczeństwo. Nowe strategie komunikacyjne, Wydawnictwo Adam Marszałek, Toruń 2008.

Upshaw L.B., Building Brand Identity, John Wiley \& Sons Inc., New York 1995.

Wipperfürth A., Brand hijack, czyli marketing bez marketingu, One Press, Gliwice 2010. 